\title{
The Effect of Substituted Benzene-Sulfonamides and Clinically Licensed Drugs on the Catalytic Activity of CynT2, a Carbonic Anhydrase Crucial for Escherichia coli Life Cycle
}

\author{
Sonia Del Prete ${ }^{1}$, Viviana De Luca ${ }^{1,2}$, Silvia Bua ${ }^{3}$, Alessio Nocentini ${ }^{3}{ }^{(}$, Vincenzo Carginale $^{1}(\mathbb{D}$, \\ Claudiu T. Supuran ${ }^{3, *(1)}$ and Clemente Capasso ${ }^{1, *}$ (i) \\ 1 Institute of Biosciences and Bioresources, CNR, Via Pietro Castellino 111, 80131 Napoli, Italy; \\ sonia.delprete@ibbr.cnr.it (S.D.P.); vivianadeluca.81@gmail.com (V.D.L.); vincenzo.carginale@cnr.it (V.C.) \\ Proteomics \& Mass Spectrometry Laboratory, ISPAAM, CNR, Via Argine 1085, 80147 Naples, Italy \\ 3 Section of Pharmaceutical and Nutraceutical Sciences, Department of Neurofarba, University of Florence, \\ Via U. Schiff 6, Sesto Fiorentino, 50019 Florence, Italy; silvia.bua@unifi.it (S.B.); \\ alessio.nocentini@unifi.it (A.N.) \\ * Correspondence: claudiu.supuran@unifi.it (C.T.S.); clemente.capasso@ibbr.cnr.it (C.C.); \\ Tel.: +39-055-4573729 (C.T.S.); +39-081-613-2559 (C.C.)
}

Received: 22 May 2020; Accepted: 9 June 2020; Published: 11 June 2020

\begin{abstract}
Proteins are relevant antimicrobial drug targets, and among them, enzymes represent a significant group, since most of them catalyze reactions essential for supporting the central metabolism, or are necessary for the pathogen vitality. Genomic exploration of pathogenic and non-pathogenic microorganisms has revealed genes encoding for a superfamily of metalloenzymes, known as carbonic anhydrases (CAs, EC 4.2.1.1). CAs catalyze the physiologically crucial reversible reaction of the carbon dioxide hydration to bicarbonate and protons. Herein, we investigated the sulfonamide inhibition profile of the recombinant $\beta$-CA (CynT2) identified in the genome of the Gram-negative bacterium Escherichia coli. This biocatalyst is indispensable for the growth of the microbe at atmospheric $\mathrm{pCO}_{2}$. Surprisingly, this enzyme has not been investigated for its inhibition with any class of CA inhibitors. Here, we show that CynT2 was strongly inhibited by some substituted benzene-sulfonamides and the clinically used inhibitor sulpiride $\left(\mathrm{K}_{\mathrm{I}} \mathrm{s}\right.$ in the range of $\left.82-97 \mathrm{nM}\right)$. This study may be relevant for identifying novel CA inhibitors, as well as for another essential part of the drug discovery pipeline, such as the structure-activity relationship for this class of enzyme inhibitors.
\end{abstract}

Keywords: carbonic anhydrase; sulfonamides; inhibitors; antibacterials; Escherichia coli; stopped-flow assay; protonography

\section{Introduction}

The first wholly sequenced microbial genomes were obtained in 1995 from two pathogenic bacteria, Haemophilus influenzae and Mycoplasma genitalium [1,2]. From 1995 onward, genomes belonging to 11,691 eukaryotes, 247,392 prokaryotes, and 34,747 viruses have been sequenced (Data from National Center for Biotechnology Information, May 2020). The extensive DNA sequencing has opened a new era to contrast human, animal, and plant diseases [3]. Two main reasons support this. The first is that most of the sequenced genomes belong to pathogens, and the second is that the knowledge of the genome of harmful microbes offers the possibility to identify gene encoding for protein targets, whose inhibition might impair the growth or virulence of the prokaryotic and eukaryotic pathogens $[4,5]$. Proteins as drug targets are prevalent. Among them, enzymes represent a significant 
group, since most of them catalyze reactions essential for supporting the central microbe metabolism and, as a consequence, the vitality of the pathogen [6]. The basis of the drug target approach is supported by the following criteria: (a) to identify metabolic pathways which are absent in the host and indispensable for the survival of the pathogen; (b) to recognize enzymes of the metabolic pathway whose inhibition compromise the microbe lifecycle; and, finally, (c) to find compounds which, in vitro (as the first investigation), can interfere with the activity of the identified enzymes [7]. In this context, the genome exploration of pathogenic and non-pathogenic microorganisms has revealed genes encoding for a superfamily of metalloenzymes, known as carbonic anhydrases (CAs, EC 4.2.1.1) [8-12]. CAs catalyze the physiologically crucial reversible reaction of the carbon dioxide $\left(\mathrm{CO}_{2}\right)$ hydration to bicarbonate $\left(\mathrm{HCO}_{3}{ }^{-}\right)$and protons $\left(\mathrm{H}^{+}\right)$according to the following chemical reaction: $\mathrm{CO}_{2}+\mathrm{H}_{2} \mathrm{O} \leftrightharpoons \mathrm{HCO}_{3}^{-}+\mathrm{H}^{+}$[13-15]. Many CA inhibitors (CAIs) exist and efficiently inhibit, in vitro, the activity of the CAs encoded by the genome of several pathogens [13,16-18]. It has been demonstrated that CAIs are also effective in vivo, impairing the growth and virulence of several pathogens responsible of human diseases, such as Helicobacter pylori [19-21], Vibrio cholerae [22], Brucella suis [23-26], Salmonella enterica [27], and Pseudomonas aeruginosa [28]. Considering the three major criteria typifying the drug-target approach, it is evident that CAs meet the criteria (b) and (c) entirely. Instead, the criterion (a) is satisfied partly because CAs are ubiquitous metalloenzymes involved in the balance of the equilibrium between dissolved $\mathrm{CO}_{2}$ and $\mathrm{HCO}_{3}{ }^{-}$in all living organisms. Even if CAs are not species-specific enzymes, they are considered promising drug targets because they offer the possibility to design specific and selective inhibitors for the microbial CAs [13,16-18]. For example, the enzyme dihydrofolate reductase (DHFR), although it is ubiquitously expressed in all kingdoms, is a target of several drugs, such as the antibacterial trimethoprim [29]. This enzyme is responsible for the nicotinamide adenine dinucleotide phosphate (NADPH)-dependent reduction of 5,6-dihydrofolate (DHF) to 5,6,7,8-tetrahydrofolate (THF), an essential cofactor used in the biosynthetic pathways of purines, thymidylate, methionine, glycine, pantothenic acid, and $N$-formyl-methionyl tRNA. The bacterial DHFR amino acid sequence has an identity of $30 \%$ with the corresponding human protein [29]. Nevertheless, trimethoprim selectively inhibits the bacterial enzyme but not the human DHFR [29].

The CA superfamily is grouped into eight genetically distinct families (or classes), named with the Greek letters $\alpha, \beta, \gamma, \delta, \zeta, \eta, \theta$, and ı [13-15,30,31]. In mammalian, for example, 15 CAs are expressed, 12 of which are catalytically active, and all belong to the $\alpha$-class [9,16,32-37]. It is interesting to stress that the genome of most pathogens does not encode for a $\alpha$-CA $[12-14,34,38,39]$. This is a unique advantage in finding inhibitors with no inhibitory effect on the CAs from humans and animals. However, when the genome of a pathogen encodes for a $\alpha$-CA, such enzyme (amino acid sequence identity of about $35 \%$ respect to the mammalian protein) shows structural differences in the amino acid residues surrounding the catalytic pocket, offering the possibility to tune the CA inhibitors and, hence, a higher probability to inhibit selectively the $\alpha$-CA identified in the pathogen [40-42]. Recently, our groups focused on the in vitro inhibition of recombinant $\beta$-CA (CynT2) from Escherichia coli because this $\mathrm{CA}$, localized in the cytoplasm, is indispensable for the growth of the microbe at atmospheric $\mathrm{pCO}_{2}[43,44]$. E. coli is a Gram-negative bacterium that, as a commensal microorganism, colonizes the lower intestine of warm-blooded organisms [45-47]. In some cases, E. coli can act as a severe pathogen able to generate disease outbreaks worldwide [48-50], or, as an opportunistic pathogen, which can cause diseases if the host defenses are weakened [51]. Surprisingly, although this enzyme was reported and crystallized two decades ago [43], no inhibition study with any class of CAIs was reported so far. Here, we compare the inhibition profiles of CynT2 with those determined for the $\beta$-CA from Vibrio cholerae and the two human $\alpha$-CA isoforms (hCA I and hCA II), using the sulfonamides and their bioisosteres, which, among the groups of the classical CAIs, generally inhibit the other CAs in the range of nanomolar and have been clinically used for decades as antiglaucoma [29], diuretic [35], antiepileptic [32], anti-obesity [52,53], and anticancer [37] agents. 
The goal of the present manuscript is to identify putative compounds, which can eventually go through the other phases of the drug discovery pipeline, such as the structure-activity relationship (SAR), in vitro cell based-tests, in vivo studies, and, finally, the clinical trials, leading to the discovery of new antibacterials.

\section{Results and Discussion}

\subsection{Production and Enzymatic Activity of the Target CynT2}

Generally, the bacterial genome contains genes encoding for at least four CA-classes categorized as $\alpha, \beta, \gamma$, and $\iota[12,14,15,29,38]$. The $E$. coli genome analysis allowed the identification of genes encoding for CAs belonging to one of the following classes: $\beta, \gamma$, and ı. Among them, two $\beta$-CAs isoforms, indicated with the acronyms CynT and CynT2, were investigated for their physiological function, as well as their involvement in the life cycle of E. coli. It has been demonstrated that CynT, catalyzing the $\mathrm{CO}_{2}$ hydration, prevents the diffusion of $\mathrm{CO}_{2}$ from the cell and produces the bicarbonate essential for the neutralization of the toxic cyanate through the reaction catalyzed by the enzyme cyanase $\left(\mathrm{NCO}^{-}+3 \mathrm{H}^{+}+\mathrm{HCO}_{3}{ }^{-} \rightarrow 2 \mathrm{CO}_{2}+\mathrm{NH}_{4}{ }^{+}\right)$[54]. Instead, the CynT2 isoform is required for E. coli growth at low $\mathrm{CO}_{2}$ concentrations (atmospheric $\mathrm{pCO}_{2}$ ), as demonstrated by experiments reported in the literature $[43,44]$. Thus, with both enzymes being involved in the cellular balance of $\mathrm{CO}_{2}$ and bicarbonate, their inhibition was hypothesized to impair bacterial growth and virulence [44].

Using the recombinant DNA technology, CynT2 was heterologously overexpressed in recombinant form in this work. The biocatalyst was produced as a fusion protein with six tandem histidines $\left(\mathrm{His}_{6}-\mathrm{Tag}\right)$ at the $\mathrm{N}$-terminus of the polypeptide chain. The chimeric protein was purified from the soluble cytoplasmic protein fraction of the bacterial host cells, using a nickel-charged resin with high affinity for the polyhistidine sequence. CynT2 showed a high degree of purity, as demonstrated by SDS-PAGE (Figure 1).
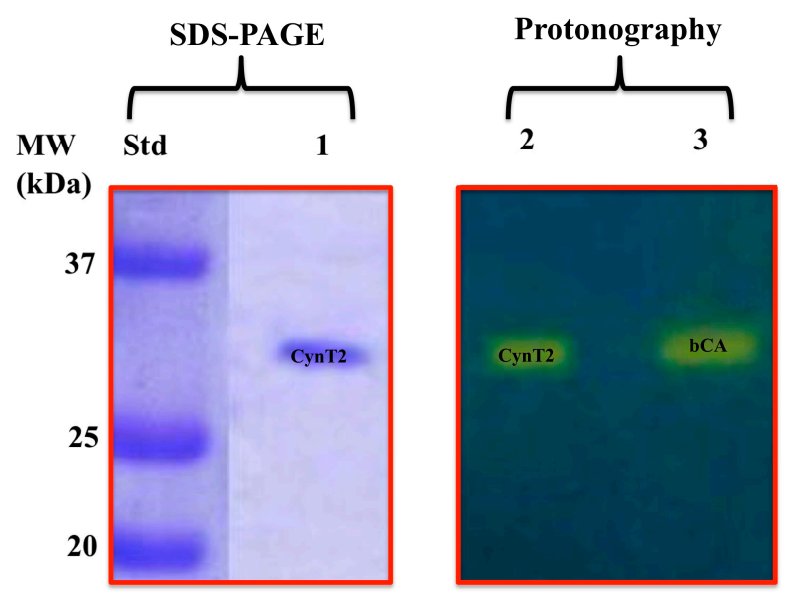

Figure 1. Analysis of the heterologous protein expression on the Coomassie Blue stained gel (SDS-PAGE) and Bromothymol Blue stained gel (Protonography). The purified recombinant CynT2 was eluted from the affinity resin by adding $250 \mathrm{mM}$ imidazole. The yellow band on the protonogram (right of the figure) corresponds to the enzyme activity responsible for the drop of $\mathrm{pH}$ from 8.2 to the transition point of the dye in the control buffer. Lane STD, molecular markers (form bottom to the top: 20, 25, and $37 \mathrm{kDa}$ ); Lane STD, Molecular markers; Lane 1, purified CynT2; Lane 2, purified CynT2 subjected to protonography; Lane 3, commercial bovine CA (bCA) used as a positive control in the protonography.

After the electrophoretic run, the polyacrylamide gel showed a single protein band (CynT2 as the fusion protein) with an apparent molecular weight of about $29.0 \mathrm{kDa}$ (the theoretical mass of the chimeric CynT2 based on its amino acid sequence was $29.0 \mathrm{kDa}$ ) (Figure 1). Following the SDS-PAGE, CynT2 was subject to protonographic analysis, which is a facile new technique developed by us to 
identify the hydratase activity of CAs on SDS-PAGE [55]. The protonography study demonstrated that the recombinant CynT2 was catalytically active on the polyacrylamide gel, as evidenced by the yellow band due to the hydratase activity in correspondence of the molecular weight of the purified chimeric molecule (Figure 1). The protonogram was obtained by using the recombinant CynT2 from E. coli, and the commercial bovine $\alpha$-CA (bCA) was used as a positive control. It is known that the mammalian $\alpha$-CAs are monomeric [9,34]. The protonogram developed from the similar analysis of bCA (mammalian enzyme) showed a single band of activity corresponding to a monomer of about $30 \mathrm{kDa}$ (Figure 1, lane 3). In contrast, all the bacterial $\beta$-CAs crystallized so far are active as dimers or tetramers [13], with two or four identical active sites. The protonogram of CynT2 showed a band of activity (Figure 1) in the correspondence of its monomer $(29.0 \mathrm{kDa})$. The yellow band appeared in the position of the inactive monomeric form of CynT2, because, at the end of the electrophoretic run, the SDS is removed from the gel. This procedure leads to the rearrangement of the $\beta$-CA monomers in the gel, and the final result is the reconstitution of the active dimeric or tetrameric forms of the $\beta$-CA. This also means that CynT2, after the elimination of the SDS from the gel, can refold and generate the active form correctly, as reported for other CA classes present in prokaryotic/eukaryotic organisms [55].

The $\mathrm{CO}_{2}$ hydratase activity of the purified and soluble enzyme and its kinetic constants were determined by using the stopped-flow technique. It should be mentioned that, in the initial report of Cronk et al. [43], the enzyme was reported to possess catalytic activity, but the kinetic parameters were not reported, as a rather simple assay was used which does not offer the possibility to easily measure $\mathrm{k}_{\mathrm{cat}}$ and $\mathrm{K}_{\mathrm{m}}$ of the enzyme. Thus, we report these measurement and the obtained results are compared with the kinetic parameters of the two mammalian $\alpha$-CA isoforms (h CAI and h CAII) and the $\alpha-, \beta-, \gamma-$, and I-CAs from different species of pathogenic bacteria, such Vibrio cholerae, Porphyromonas gingivalis, Helicobacter pylori, and Burkholderia territorii (Table 1).

Table 1. Kinetic parameters for the $\mathrm{CO}_{2}$ hydration reaction catalyzed by the human $\alpha$-CAs: the cytosolic isozymes hCA I and II; bacterial $\alpha$-CA: VchCA $\alpha$; bacterial $\beta$-CAs: CynT2, VchCA $\beta$, PgiCA $\beta, \mathrm{HpyCA} \beta$, BsuCA219, BsuCA213, LpCA1 and LpCA2; bacterial $\gamma$-CAs: PgiCA $\gamma$, VchCA $\gamma$; bacterial ı-CA: BteCAı. All the measurements were made at $20^{\circ} \mathrm{C}, \mathrm{pH} 7.5$ ( $\alpha$-enzymes), and $\mathrm{pH} 8.3$ ( $\beta-{ }^{-}, \gamma^{-}$, and $\mathrm{\iota -}$ enzymes), by a stopped-flow $\mathrm{CO}_{2}$ hydrase assay method.

\begin{tabular}{|c|c|c|c|c|c|}
\hline Organism & Acronym & Class & ${ }^{1} k_{\text {cat }}\left(\mathrm{s}^{-1}\right)$ & ${ }^{1} \mathrm{k}_{\mathrm{cat}} / \mathrm{K}_{\mathrm{m}}\left(\mathrm{M}^{-1} \times \mathrm{s}^{-1}\right)$ & ${ }^{1} K_{I}$ (Acetazolamide) (nM) \\
\hline \multirow[t]{2}{*}{ Homo sapiens ${ }^{a}$} & hCA I & $\alpha$ & $2.0 \times 10^{5}$ & $5.0 \times 10^{7}$ & 250 \\
\hline & hCA II & $\alpha$ & $1.4 \times 10^{6}$ & $1.5 \times 10^{8}$ & 12 \\
\hline Vibrio cholerae $^{\text {a }}$ & $\mathrm{V} \operatorname{chCA} \alpha$ & $\alpha$ & $8.2 \times 10^{5}$ & $7.0 \times 10^{7}$ & 6.8 \\
\hline Escherichia coli & CynT2 & $\beta$ & $5.3 \times 10^{5}$ & $4.1 \times 10^{7}$ & 227 \\
\hline Vibrio cholerae ${ }^{\mathrm{a}}$ & $\mathrm{VchCA} \beta$ & $\beta$ & $3.3 \times 10^{5}$ & $4.1 \times 10^{7}$ & 451 \\
\hline Porphyromonas gingivalis $b$ & PgiCA $\beta$ & $\beta$ & $2.8 \times 10^{5}$ & $1.5 \times 10^{7}$ & 214 \\
\hline Helicobacter pylori ${ }^{\mathrm{c}}$ & НруСА $\beta$ & $\beta$ & $7.1 \times 10^{5}$ & $4.8 \times 10^{7}$ & 40 \\
\hline Porphyromonas gingivalis $\mathrm{b}$ & PgiCA $\gamma$ & $\gamma$ & $4.1 \times 10^{5}$ & $5.4 \times 10^{7}$ & 324 \\
\hline Vibrio cholerae ${ }^{\text {a }}$ & $\mathrm{VchCA} \gamma$ & $\gamma$ & $7.3 \times 10^{5}$ & $6.4 \times 10^{7}$ & 473 \\
\hline Burkholderia territorii $\mathrm{d}$ & BteCAı & $\imath$ & $3.0 \times 10^{5}$ & $9.7 \times 10^{7}$ & 65 \\
\hline
\end{tabular}

${ }^{1}$ Mean from three different assays by a stopped-flow technique (errors were in the range of $\pm 5-10 \%$ of the reported values); ${ }^{a}$ from Reference [56]; ${ }^{b}$ from Reference [35]; ${ }^{c}$ from Reference [19]; ${ }^{\mathrm{d}}$ from Reference [15].

CynT2 resulted in being an excellent catalyst for the $\mathrm{CO}_{2}$ hydration reaction $\left(\mathrm{k}_{\mathrm{cat}}=5.3 \times 10^{5} \mathrm{~s}^{-1}\right.$ and a $\mathrm{k}_{\mathrm{cat}} / \mathrm{K}_{\mathrm{M}}=4.1 \times 10^{7} \mathrm{M}^{-1} \mathrm{~s}^{-1}$ ). It was inhibited by acetazolamide (AAZ), a well-known pharmacological CA inhibitor, with a $\mathrm{K}_{\mathrm{I}}=227 \mathrm{nM}$ (Table 1). Interestingly, all the bacterial enzymes were slightly more active than the human isoform h CAI, which sowed a $\mathrm{k}_{\mathrm{cat}}=2.0 \times 10^{5} \mathrm{~s}^{-1}$. From the results reported in Table 1, it emerged that the clinically used sulfonamide had a different sensitivity versus the two human $\alpha$-CAs and the bacterial enzymes. The isoform hCA I was inhibited with a $\mathrm{K}_{\mathrm{I}}=250 \mathrm{nM}$, which is very similar to the values obtained for the most bacterial $\beta$-CAs and $\gamma$-CAs, whereas the human isoform h CA II, as well as the bacterial $\beta$-CAs from H. pylori, V. cholerae, and B. territorii, resulted in being more sensitive to the $\mathbf{A A Z}$ inhibition with a $\mathrm{K}_{\mathrm{I}}$ in the range from 6.8 to $65 \mathrm{nM}$ (Table 1). 
Here, we stress again that the $\beta$-CAs are metalloenzymes, which use as catalytic metal the $\mathrm{Zn}$ (II) ion, which is coordinated by one His and two Cys residues in the enzymatic catalytic pocket (Figure 2). The fourth ligand is a water molecule/hydroxide ion acting as a nucleophile in the enzyme's catalytic cycle. The comparison of the amino acid sequence CynT2 with those of each $\beta$-CAs indicated in Table 1 evidenced that, even if these proteins belong to the same class ( $\beta$-class), they are very variegated in the sequence identity, the ratio of the number of identical amino acids in the sequence to the total number of amino acids. Figure 2 shows that CynT2 had 61, 19, and 26\% identity compared with the $\mathrm{VcCA} \beta$, PgiCA $\beta$, and $\mathrm{HpyCA} \beta$, respectively. The catalytic pocket is highly conserved for this CA-class, as also happens for the other CA-classes, but the diversity of the amino acids surrounding the catalytic site influence the biocatalyst kinetic properties and the interaction of the inhibitor, with the enzyme provoking differences in the inhibition constant $\mathrm{K}_{\mathrm{I}}$ (see Table 1).

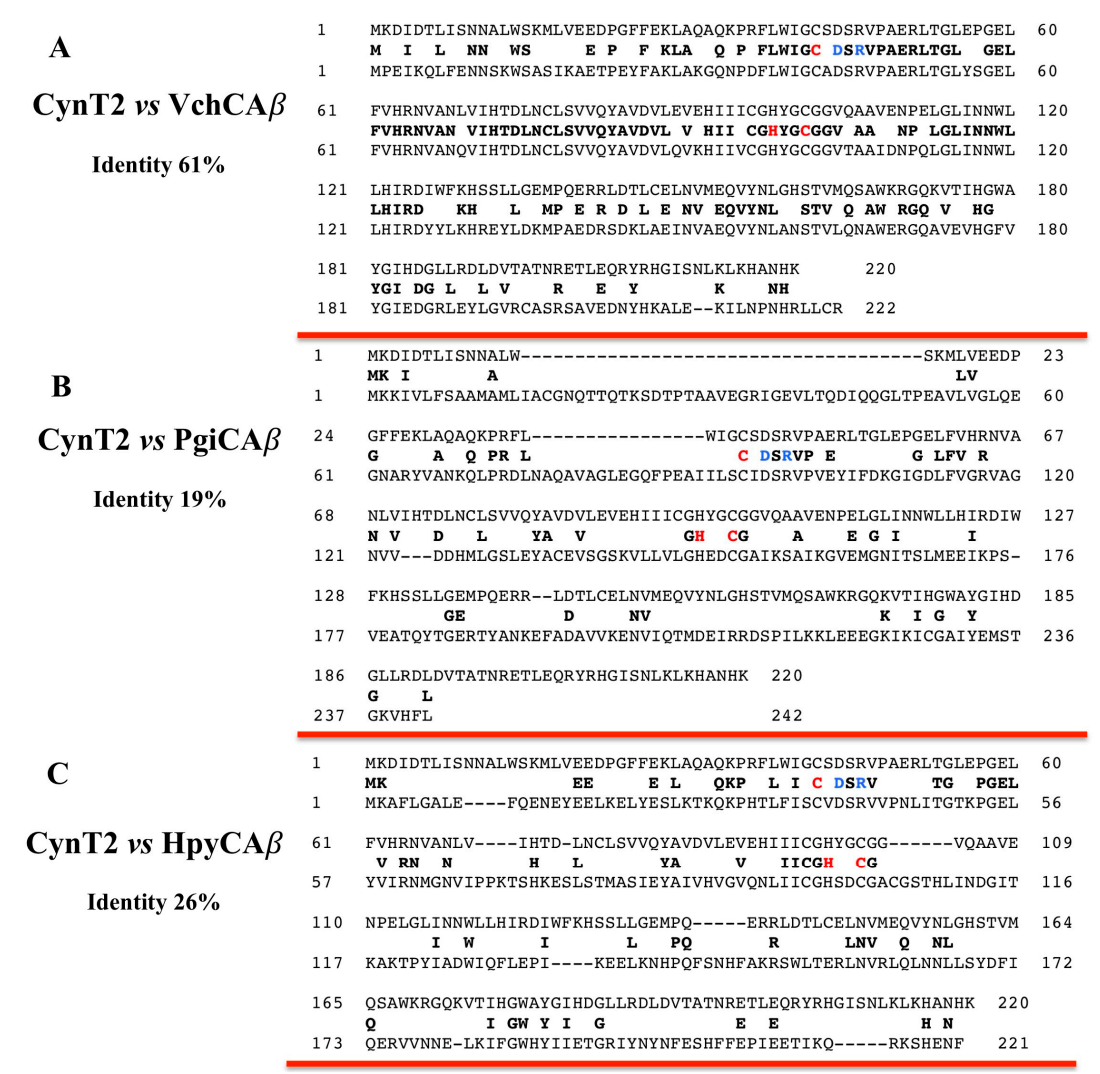

Figure 2. Pairwise comparison of the CynT2 polypeptide chain with VchCA $\beta$ (A), PigCA $\beta$ (B), and НруСА $\beta$ (C) amino acid sequences, respectively. The identical amino acid residues are indicated between the two aligned amino acid sequences (black bold). The amino acid residues participating in the coordination of the metal ion are indicated in red (Cys, His, and Cys), whereas the catalytic dyad involved in the activation of the water molecule coordinated to zinc (Asp-Arg) is shown in blue. The pairwise alignment was performed with the program Blast Global Align. The accession numbers of the aligned sequences are: EEW0221051.1, CynT2 from Escherichia coli; WP_002051193.1, VchCA $\beta$ from Vibrio cholerae; WP_012458351.1, PgiCA $\beta$ from Porphyromonas gingivalis; WP_000642991.1, HpyCA $\beta$ from Helicobacter pylori.

\subsection{CynT2 Sulfonamide Inhibition Profile}

The exploration of the inhibition profiles of the CAs from different bacterial species is crucial, especially for discovering potent and selective inhibitors, which can be used as a scaffold for designing novel antibacterials interfering with the microbial CA activity and, thus, impairing the microbial life cycle or their virulence without altering the host (human or animal) metabolism. This aspect is fascinating, considering the emergence arisen from the resistance to the existing antimicrobial drugs, 
which is one of the most severe problems afflicting the human community. Recently, we demonstrated that CynT2 was inhibited efficiently by series of metal-complexing small molecules, including sulfamide, sulfamate, phenylboronic acid, phenylarsonic acid, and diethyldithiocarbamate $\left(\mathrm{K}_{\mathrm{I}}=2.5\right.$ to $\left.84 \mu \mathrm{M}\right)$ (accepted by Molecules and in press). Here, a relatively large number of sulfonamides and their bioisosteres have been investigated for their interaction with CynT2. A library of 42 compounds, 41 primary sulfonamides, and one sulfamate, were used as CAIs (Figure 3).
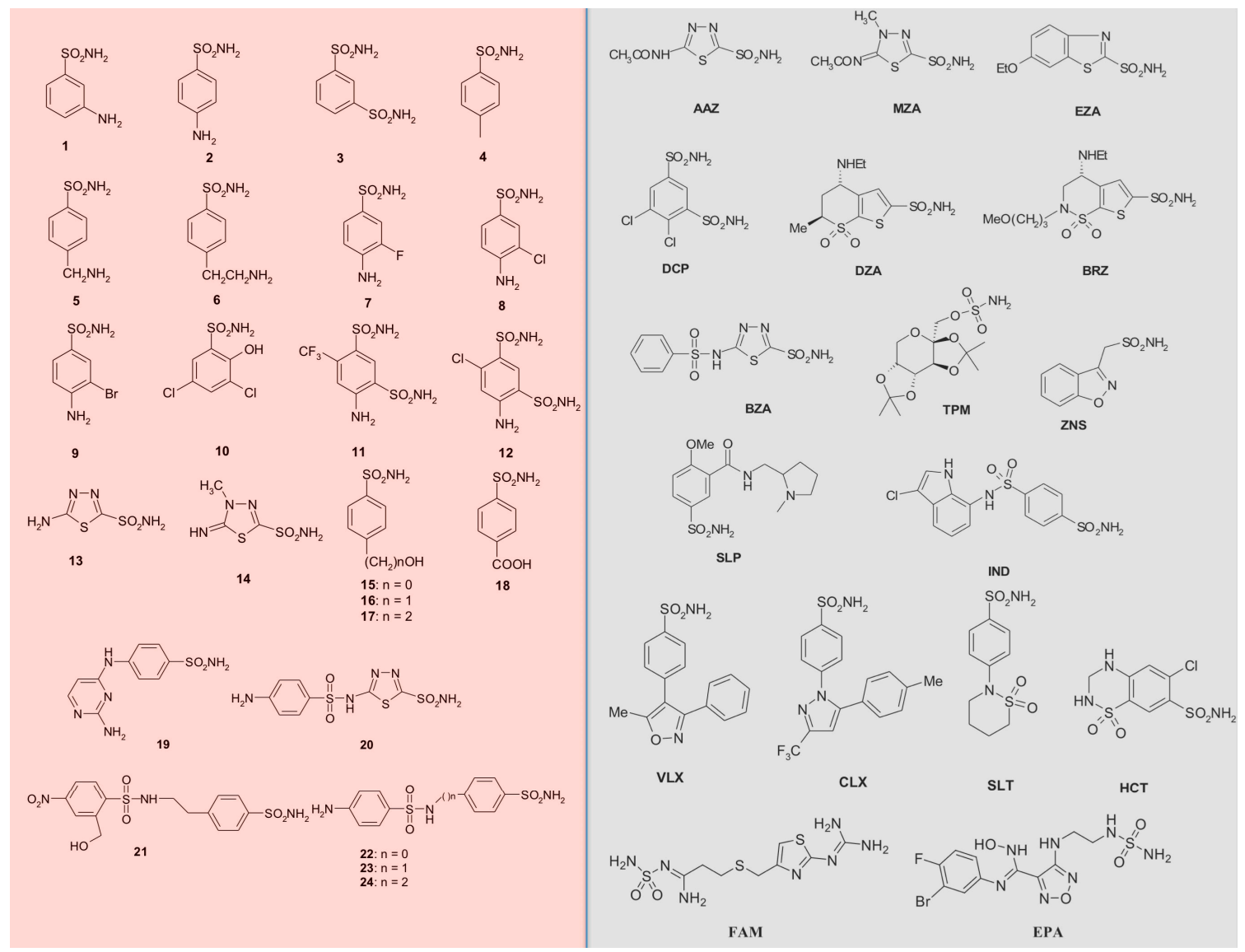

Figure 3. The 42 compounds used to study CynT2 inhibitory behavior. Forty-one sulfonamides and one sulfamate (TPM) were exploited. In red, the series 1-24; in gray, the clinically used drugs.

Derivatives 1-24 and AAZ-EPA are either simple aromatic/heterocyclic sulfonamides widely used as building blocks for obtaining new potent and selective families of such pharmacological agents. Table 2 shows a summary of the clinical treatments that use compounds of the series AAZ-EPA [32,57,58].

Table 2. Inhibitor name, commercial name, acronym, and clinical treatment of the CAI clinically used drugs.

\begin{tabular}{cccc}
\hline Inhibitor Name & Trade Name & Acronym & Clinical Treatment \\
\hline Acetazolamide & Diamox & AAZ & glaucoma, epilepsy, altitude sickness, periodic paralysis, idiopathic \\
intracranial hypertension, diuretic \\
Methazolamide & Neptazane & MZA & glaucoma \\
Ethoxzolamide & Cadrase & EZA & glaucoma, duodenal ulcers, diuretic \\
Dichlorophenamide & Keveyis & DCP & glaucoma, diuretic \\
Dorzolamide & Trusopt & DZA & glaucoma \\
Brinzolamide & Azopt & BRZ & glaucoma \\
Benzolamide & No generic name & BZA & glaucoma \\
\hline
\end{tabular}


Table 2. Cont.

\begin{tabular}{|c|c|c|c|}
\hline Inhibitor Name & Trade Name & Acronym & Clinical Treatment \\
\hline Topiramate & Topamax & TMP & epilepsy, migraine \\
\hline Zonisamide & Zonegran & ZNS & epilepsy, Parkinson's disease, obesity, migraine, bipolar depression \\
\hline Sulpiride & Dogmatil & SLP & psychosis, schizophrenia, anxiety, mild depression \\
\hline Indisulam & No generic name & IND & cancer \\
\hline Valdecoxib & Bextra & VLX & $\begin{array}{c}\text { osteoarthritis, rheumatoid arthritis, painful menstruation, } \\
\text { menstrual symptoms }\end{array}$ \\
\hline Celecoxib & Celebrex & CLX & $\begin{array}{l}\text { osteoarthritis, acute pain in adults, rheumatoid arthritis, ankylosing } \\
\text { spondylitis, painful menstruation, juvenile rheumatoid arthritis }\end{array}$ \\
\hline Sulthiame & Ospolot & SLT & epilepsy \\
\hline Saccharin & No generic name & SAC & diet \\
\hline Hydrochlorothiazide & CAPOZIDE & HCT & $\begin{array}{c}\text { hypertension, congestive heart failure, symptomatic edema, diabetes } \\
\text { insipidus, renal tubular acidosis }\end{array}$ \\
\hline $\begin{array}{l}\text { Famotidine } \\
\text { Epacadostat }\end{array}$ & $\begin{array}{c}\text { Pepcid } \\
\text { No generic name }\end{array}$ & $\begin{array}{l}\text { FAM } \\
\text { EPA }\end{array}$ & $\begin{array}{c}\text { peptic ulcer, gastroesophageal reflux disease, } \\
\text { cancer }\end{array}$ \\
\hline
\end{tabular}

Generally, AAZ, MZA, EZA, and DCP are systemically acting antiglaucoma CAIs. DZA and BRZ are antiglaucoma agents that function topically; BZA is an orphan drug of this pharmacological class. ZNS, SLT, and the sulfamic acid ester TPM are widely used antiepileptic drugs. SLP and IND also belong to this class of pharmacological agents, together with the COX2 selective inhibitors CLX and VLX. SAC and the diuretic HCT are also known to act as CAIs. In this study, we also considered FAM (a competitive histamine H2-receptor antagonist) and EPA (an inhibitor of the heme-containing enzyme, indoleamine 2,3-dioxygenase-1 (IDO1)). Most of the sulfonamides, such as the clinically used derivatives AAZ, MZA, EZA, DCP, DZA, and BZA, bind in a tetrahedral geometry to the Zn(II) ion in the deprotonated state, with the nitrogen atom of the sulfonamide moiety coordinated to $\mathrm{Zn}$ (II) and an extended network of hydrogen bonds, involving amino acid residues of the enzyme, also participating in the anchoring of the inhibitor molecule to the metal ion $[16,18,53]$. The aromatic/heterocyclic part of the inhibitor interacts with the hydrophilic and hydrophobic residues of the catalytic cavity $[16,53]$.

Table 3 reports the inhibition profile of CynT2. Moreover, a comparative analysis was carried out, analyzing the CynT2 inhibitory behavior with those obtained for the enzyme VchCA $\beta$ ( $\beta$-CA form Vibrio cholerae) [59] and the two human $\alpha$-CA isoforms, hCA I and hCA II [32,60].

Table 3. Inhibition of the human isoforms hCA I and hCA II and the two bacterial $\beta$-CAs (CynT2 and VchCA $\beta$ ) with sulfonamides 1-24 and the clinically used drugs AAZ-EPA.

\begin{tabular}{ccccc}
\hline \multirow{2}{*}{ Inhibitor } & \multicolumn{4}{c}{$\mathbf{K}_{\mathbf{I}}{ }^{*}(\mathbf{n M})$} \\
\cline { 2 - 5 } & hCA I $^{\mathbf{a}}$ & hCA II $^{\mathbf{a}}$ & CynT2 & ${\text { VchCA } \boldsymbol{\beta}^{\mathbf{a}}}$ \\
\hline $\mathbf{1}$ & $\mathbf{2 8 , 0 0 0}$ & $\mathbf{3 0 0}$ & 705 & 463 \\
$\mathbf{2}$ & 25,000 & 240 & 790 & 447 \\
$\mathbf{3}$ & 79 & 8 & 457 & 785 \\
$\mathbf{4}$ & 78,500 & 320 & 3015 & $>10,000$ \\
$\mathbf{5}$ & 25000 & 170 & 2840 & $>10,000$ \\
$\mathbf{6}$ & 21,000 & 160 & 3321 & $>10,000$ \\
$\mathbf{7}$ & 8300 & 60 & $>10,000$ & $>10,000$ \\
$\mathbf{8}$ & 9800 & 110 & $>10,000$ & 9120 \\
$\mathbf{9}$ & 6500 & 40 & 2712 & $>10,000$ \\
$\mathbf{1 0}$ & 7300 & 54 & 8561 & $>10,000$ \\
$\mathbf{1 1}$ & 5800 & 63 & 6246 & 879 \\
$\mathbf{1 2}$ & 8400 & 75 & 4385 & 4450 \\
$\mathbf{1 3}$ & 8600 & 60 & 4122 & 68,1 \\
$\mathbf{1 4}$ & 9300 & 19 & 440 & 82,3 \\
$\mathbf{1 5}$ & 5500 & 80 & 6445 & 349 \\
$\mathbf{1 6}$ & 9500 & 94 & 2340 & 304 \\
\hline
\end{tabular}


Table 3. Cont.

\begin{tabular}{|c|c|c|c|c|}
\hline \multirow{2}{*}{ Inhibitor } & \multicolumn{4}{|c|}{$\mathrm{K}_{\mathrm{I}}{ }^{*}(\mathrm{nM})$} \\
\hline & hCA I ${ }^{a}$ & hCA II $^{\text {a }}$ & CynT2 & $\mathrm{VchCA} \beta^{\mathrm{a}}$ \\
\hline 17 & 21,000 & 125 & 502 & 3530 \\
\hline 18 & 164 & 46 & 205 & 515 \\
\hline 19 & 109 & 33 & 416 & 2218 \\
\hline 20 & 6 & 2 & 726 & 859 \\
\hline 21 & 69 & 11 & 473 & 4430 \\
\hline 22 & 164 & 46 & 93 & 757 \\
\hline 23 & 109 & 33 & 322 & 817 \\
\hline 24 & 95 & 30 & 82 & 361 \\
\hline AAZ & 250 & 12 & 227 & 4512 \\
\hline MZA & 50 & 14 & 480 & 6260 \\
\hline EZA & 25 & 8 & 557 & 6450 \\
\hline DCP & 1200 & 38 & $>10,000$ & 2352 \\
\hline DZA & 50,000 & 9 & 629 & 4728 \\
\hline BRZ & 45,000 & 3 & 2048 & 845 \\
\hline BZA & 15 & 9 & 276 & 846 \\
\hline TPM & 250 & 10 & 3359 & 874 \\
\hline ZNS & 56 & 35 & 3189 & 8570 \\
\hline SLP & 1200 & 40 & 97 & 6245 \\
\hline IND & 31 & 15 & 2392 & 7700 \\
\hline VLX & 54,000 & 43 & 2752 & 8200 \\
\hline CLX & 50,000 & 21 & 1894 & 4165 \\
\hline SLT & 374 & 9 & 285 & 455 \\
\hline SAC & 18,540 & 5959 & 6693 & 275 \\
\hline HCT & 328 & 290 & 5010 & 87 \\
\hline FAM & 922 & 58 & 2769 & - \\
\hline EPA & 8262 & 917 & 2560 & - \\
\hline
\end{tabular}

* Errors in the range of $5-10 \%$ of the reported data, from three different assays. ${ }^{a}$ Human recombinant isozymes and Vibrio enzyme, stopped-flow data from Reference [56]; -, not detected.

From the data of Table 3, the following can be observed:

i. The two homologous bacterial enzymes showed a sulfonamide inhibition pattern different from each other. In this context, it is relevant to note that the compounds 22, 24 and the clinically used inhibitor SLP were the best CynT2 inhibitors, showing a $\mathrm{K}_{\mathrm{I}}$ in the range of 82-97 nM. HTC is the only inhibitor in Table 2 that inhibited the bacterial VchCA $\beta$ with a $K_{I}=87 \mathrm{nM}$. Exciting is the fact that the inhibitory behaviors of the two bacterial biocatalysts resulted in being highly distinct from those of the two human isoenzymes. The compound HTC inhibited the human isoforms, hCA I and h CAII, with a $\mathrm{K}_{\mathrm{I}}$ value of 290 and $328 \mathrm{nM}$, respectively. Even if it is challenging to identify selective inhibitors for the bacterial CAs, HTC represents a good example, resulting in medially 3.5 times more efficiently versus the VchCA $\beta$ than the human CAs. However, it is also true that HTC is a harmful inhibitor for the Escherichia coli enzyme $\left(\mathrm{K}_{\mathrm{I}}=5.0 \mu \mathrm{M}\right)$, being 57 times less effective. Other examples are the inhibitors 22, 24, and SLS, which are 8, 4, and 64 times less effective versus the Vibrio enzyme, respectively, or the inhibitors 13 and 14 with a $K_{I}=68-82 \mathrm{nM}$ are considered potent inhibitors of the Vibrio enzyme. All of these offer the possibility to investigate their molecular interaction with the three-dimensional structures of CynT2 and VchCA $\beta$, identifying those structural factors responsible for the $\mathrm{K}_{\mathrm{I}}$ variations. This study allows the design of more efficient and selective inhibitors of the bacterial enzymes that worsen the $\mathrm{K}_{\mathrm{I}}$ when tested on the two human proteins.

ii. Among all the compounds investigated, 15 of them showed inhibition constants $<1.0 \mu \mathrm{M}$ for the CynT2. This is the case for compounds 1, 2, 3, 14, 17, 18, 19, 20, 21, 23, AAZ, MZA, EZA, DZA, BZA, and SLT. These compounds had the $\mathrm{K}_{\mathrm{I}}$ in the range of $0.2-0.79 \mu \mathrm{M}$. Interestingly, some of these CynT2 "strong inhibitors" were mild inhibitors of VchCA $\beta$, such as 17, 19, 21, AAZ, 
MZA, EZA, and DZA with $\mathrm{K}_{\mathrm{I}}=2.2-6.2 \mu \mathrm{M}$, and, vice versa, compounds 13 and $\mathbf{1 4}$ and the HTC compound mentioned above resulted in being more sensitive versus the Vibrio enzyme with a $\mathrm{K}_{\mathrm{I}}$ in the range of $68-87 \mathrm{nM}$.

iii. Several compounds of the series $1-24$, such as $4,5,6,9,10,11,12,13,15$, and 16, as well as inhibitors of the series AAZ-EPA, such as BRZ, TPM, IND, VLX, CLX, SAC, HTC, FAM, and EPA, had a moderate inhibitory effect on the CynT2 enzyme, showing a $\mathrm{K}_{\mathrm{I}}$ between 1.8 and $8.5 \mu \mathrm{M}$. Most of these inhibitors were efficient inhibitors of hCA II $\left(\mathrm{K}_{\mathrm{I}}=3-917 \mathrm{nM}\right)$ and weak inhibitors of the hCA I $\left(\mathrm{K}_{\mathrm{I}}=5.8-78.5 \mu \mathrm{M}\right)$, except for compound FAM $\left(\mathrm{K}_{\mathrm{I}}=0.9 \mu \mathrm{M}\right)$.

iv. Some CynT2 inhibitors showed a $\mathrm{K}_{\mathrm{I}}>10 \mu \mathrm{M}$, such as compounds 7, 8, and DCP, which resulted in a weak inhibitory activity. The weakness inhibitors for the VchCA $\beta$ were $4,5,6,7,9$, and 10. As shown in Table 3, it is apparent that the human $\alpha$-isoenzyme hCA II is efficiently inhibited by all these inhibitors $\left(K_{I}=38-320 \mathrm{nM}\right)$ and others with the $K_{I}$ in the range of 3-917 nM. The compound SAC represented the only exception having the $K_{I}=5.9 \mu \mathrm{M}$. Remarkably, half of the compounds reported in Table 3 resulted in adverse inhibitors for the isoform hCA I. This confirms how important the amino acid surrounding the catalytic pocket is in the inhibition of the enzyme.

\section{Materials and Methods}

\subsection{Chemicals and Instruments}

All the chemicals used in this study were of reagent grade and purchased from Sigma. The Affinity column (His-Trap FF) and the AKTA-Prime purification system were bought from GE Healthcare. The SX20 Stopped-Flow was obtained by the Applied Photophysics. SDS-PAGE and Western blot apparatus were procured from BioRAD.

\subsection{Heterologous Expression and Purification of the Recombinant Enzyme}

The synthetic Escherichia coli gene encoding for the CynT2 was synthesized by the Invitrogen GeneArt (ThermoFisher Scientific), a company specialized in gene synthesis, and cloned into the expression vector pET100D-Topo/CynT2. Briefly, the gene was designed to produce the recombinant CynT2 as fusion proteins with a tag containing nucleotides encoding for six histidines (His-Tag) at the amino terminus of neosynthesized recombinant protein. Competent E. coli BL21 (DE3) codon plus cells (Agilent) were transformed as described by Del Prete et al. [61]. Isopropyl $\beta$-D-1-thiogalactopyranoside (IPTG) at the concentration of $1 \mathrm{mM}$ was added to the cellular culture, to overexpress the recombinant CynT2. After growth, the cells were harvested and disrupted by sonication. Cellular extract was purified by using a nickel affinity column (His-Trap FF), which allows the interaction between the matrix functionalized with $\mathrm{Ni}^{2+}$ ion and the His-Tag at the $\mathrm{N}$-terminus of the protein. The HisTrap column $(1 \mathrm{~mL})$ was equilibrated with $20 \mathrm{~mL}$ equilibration buffer $(50 \mathrm{mM}$ Tris, $20 \mathrm{mM}$ imidazole, and $150 \mathrm{mM}$ sodium chloride, $\mathrm{pH}$ 7.5) at $1 \mathrm{~mL} / \mathrm{min}$. The supernatant from the cellular lysate was loaded onto the column, at $1 \mathrm{~mL} / \mathrm{min}$, connected with AKTA Prime. The recombinant CynT2 was eluted from the column by fluxing a linear gradient of imidazole $(0-300 \mathrm{mM})$, at a flow of $0.5 \mathrm{~mL} / \mathrm{min}$, in a buffer composed of $50 \mathrm{mM}$ Tris and $300 \mathrm{mM}$ sodium chloride, $\mathrm{pH}$ 7.5. The recovered CynT2 was 90\% pure. The protein quantification was carried out by Bradford method (BioRAD) [62]. The CA activity assay was performed as described by Capasso et al. [63]. Briefly, the assay was based on the monitoring of $\mathrm{pH}$ variation due to the catalyzed conversion of $\mathrm{CO}_{2}$ to bicarbonate. Bromothymol blue was used as the indicator of $\mathrm{pH}$ variation. The assay was performed at $0{ }^{\circ} \mathrm{C}$, and a $\mathrm{CO}_{2}$-satured solution was used as substrate. The enzyme activity was calculated by measuring the time required for Bromothymol blue to change from blue to yellow. This time is inversely related to the quantity of enzyme present in the sample and allows the calculation of the Wilbur-Anderson units, as described previously [63]. 


\subsection{SDS-PAGE and Protonography}

A $12 \%$ Sodium Dodecyl Sulfate-polyacrylamide gel electrophoresis (SDS-PAGE), prepared as described by Laemmli [64], was used, loading on the gel the recovered CynT2 from the affinity column. The gel was stained with Coomassie Brilliant Blue-R. To perform the protonography, wells of $12 \%$ SDS-PAGE gel were loaded with samples mixed with loading buffer not containing 2-mercaptoethanol and not subjected to boiling, in order to avoid protein denaturation. The gel was run at $150 \mathrm{~V}$, until the dye front ran off the gel. Following the electrophoresis, the $12 \%$ SDS-PAGE gel was subject to protonography, to detect the yellows bands due to the hydratase activity on the gel, as described previously [55,65-67].

\subsection{Kinetic Parameters and Inhibition Constants}

The $\mathrm{CO}_{2}$ hydration activity performed by the BteCAı was monitored by using an Applied Photophysics stopped-flow instrument [68]. Phenol red (at a concentration of $0.2 \mathrm{mM}$ ) was used as the indicator, working at the absorbance maximum of $557 \mathrm{~nm}$, with $20 \mathrm{mM}$ TRIS (pH 8.3) as buffer, and $20 \mathrm{mM} \mathrm{NaClO}_{4}$ (for maintaining constant the ionic strength), following the initial rates of the CA-catalyzed $\mathrm{CO}_{2}$ hydration reaction for a period of 10-100 s. To determine the kinetic parameters by Lineweaver-Burk plots and the inhibition constants, a concentration of $\mathrm{CO}_{2}$ between 1.7 and $17 \mathrm{mM}$ was used. At least six measurements of the original 5-10\% reaction were used to assess the initial velocity for each inhibitor. The uncatalyzed rates were identically determined and detracted from the total observed rates. Stock inhibitor solutions $(10-100 \mathrm{mM})$ were prepared in distilled-deionized water, and dilutions up to $0.01 \mathrm{mM}$ were done with the buffer test. Inhibitor and enzyme solutions were preincubated together for $15 \mathrm{~min}$, at room temperature, prior to assay, in order to allow for the formation of the E-I complex or for the eventual active site mediated hydrolysis of the inhibitor. The inhibition constants were obtained by non-linear least-squares methods, using PRISM 6 and the Cheng-Prusoff equation, as reported earlier $[56,69,70]$, and represent the mean from at least three different determinations. VchaCA $\beta$, hCA I, and hCA II were recombinant enzymes obtained in-house.

\section{Conclusions}

The Escherichia coli $\beta$-CA (CynT2) was heterologously overexpressed to investigate, for the first time, its inhibition profile with a group of classical CAIs inhibitors. The CAIs considered were the sulfonamides and their bioisosteres and one sulfamate, which generally inhibit the other CAs in the nanomolar range. The recombinant enzyme resulted in an excellent catalyst for the $\mathrm{CO}_{2}$ hydration reaction with a $\mathrm{k}_{\mathrm{cat}}=5.3 \times 10^{5} \mathrm{~s}^{-1}$ and a $\mathrm{k}_{\mathrm{cat}} / \mathrm{K}_{\mathrm{M}}=4.1 \times 10^{7} \mathrm{M}^{-1} \mathrm{~s}^{-1}$. The comparison of the inhibition profiles of CynT2 obtained for a bacterial enzyme $(\mathrm{VhCa} \beta)$ belonging to the same CA-class of CynT2 and those determined for the two human $\alpha$-CA isoforms evidenced:

1. The compounds 22, 24, and the clinically used SLP were the best CynT2 inhibitors sowing a $\mathrm{K}_{\mathrm{I}}$ in the range of $82-97 \mathrm{nM}$;

2. The inhibition profiles of the four proteins considered (CynT2, VchCA $\beta, \mathrm{hCA}$ I, and hCA II) are rather different from each other.

3. All the compounds showing a different behavior versus an enzyme belonging to the $\beta$ - and $\alpha$-class represent good candidates to identify, through the comparison of the three-dimensional structure of the protein with the inhibitor, the structural factors responsible for the $\mathrm{K}_{\mathrm{I}}$ variations.

The data of the inhibition profile and the structural analysis will help us in the design of antibacterials that can interfere with the CA activity and, thus, with the microbial life cycle or their virulence. This aspect is fascinating, considering the emergence arisen from the resistance to the existing antimicrobial drugs, which is one of the most severe problems afflicting the human community.

Author Contributions: Investigation, S.D.P., S.B., and V.D.L.; data curation, A.N., V.C., and C.C.; supervision, C.T.S. and C.C.; writing - original draft, C.C.; writing-review and editing, C.T.S. and C.C. All authors have read and agreed to the published version of the manuscript. 
Funding: This research received no external funding.

Acknowledgments: We are grateful to Giovanni Del Monaco for technical assistance.

Conflicts of Interest: The authors declare no conflict of interest.

\section{References}

1. Fleischmann, R.D.; Adams, M.D.; White, O.; Clayton, R.A.; Kirkness, E.F.; Kerlavage, A.R.; Bult, C.J.; Tomb, J.F.; Dougherty, B.A.; Merrick, J.M.; et al. Whole-genome random sequencing and assembly of Haemophilus influenzae Rd. Science 1995, 269, 496-512. [CrossRef]

2. Fraser, C.M.; Gocayne, J.D.; White, O.; Adams, M.D.; Clayton, R.A.; Fleischmann, R.D.; Bult, C.J.; Kerlavage, A.R.; Sutton, G.; Kelley, J.M.; et al. The minimal gene complement of Mycoplasma genitalium. Science 1995, 270, 397-403. [CrossRef]

3. Doostparast Torshizi, A.; Wang, K. Next-generation sequencing in drug development: Target identification and genetically stratified clinical trials. Drug Discov. Today 2018, 23, 1776-1783. [CrossRef]

4. Asif, M. A review of antimycobacterial drugs in development. Mini Rev. Med. Chem. 2012, 12, $1404-1418$. [PubMed]

5. Selzer, P.M.; Brutsche, S.; Wiesner, P.; Schmid, P.; Mullner, H. Target-based drug discovery for the development of novel antiinfectives. Int. J. Med. Microbiol. 2000, 290, 191-201. [CrossRef]

6. Sosa, E.J.; Burguener, G.; Lanzarotti, E.; Defelipe, L.; Radusky, L.; Pardo, A.M.; Marti, M.; Turjanski, A.G.; Fernandez Do Porto, D. Target-Pathogen: A structural bioinformatic approach to prioritize drug targets in pathogens. Nucleic Acids Res. 2018, 46, D413-D418. [CrossRef] [PubMed]

7. Manchado, E.; Huang, C.H.; Tasdemir, N.; Tschaharganeh, D.F.; Wilkinson, J.E.; Lowe, S.W. A Pipeline for Drug Target Identification and Validation. Cold Spring Harb. Symp. Quant. Biol. 2016, 81, 257-267. [CrossRef] [PubMed]

8. Annunziato, G.; Angeli, A.; D’Alba, F.; Bruno, A.; Pieroni, M.; Vullo, D.; De Luca, V.; Capasso, C.; Supuran, C.T.; Costantino, G. Discovery of New Potential Anti-Infective Compounds Based on Carbonic Anhydrase Inhibitors by Rational Target-Focused Repurposing Approaches. ChemMedChem 2016, 11, 1904-1914. [CrossRef]

9. Ozensoy Guler, O.; Capasso, C.; Supuran, C.T. A magnificent enzyme superfamily: Carbonic anhydrases, their purification and characterization. J. Enzyme Inhib. Med. Chem. 2016, 31, 689-694. [CrossRef]

10. Del Prete, S.; Vullo, D.; De Luca, V.; Carginale, V.; Ferraroni, M.; Osman, S.M.; AlOthman, Z.; Supuran, C.T.; Capasso, C. Sulfonamide inhibition studies of the beta-carbonic anhydrase from the pathogenic bacterium Vibrio cholerae. Bioorg. Med. Chem. 2016, 24, 1115-1120. [CrossRef]

11. Del Prete, S.; De Luca, V.; De Simone, G.; Supuran, C.T.; Capasso, C. Cloning, expression and purification of the complete domain of the eta-carbonic anhydrase from Plasmodium falciparum. J. Enzyme Inhib. Med. Chem. 2016, 31, 54-59. [CrossRef]

12. Capasso, C.; Supuran, C.T. An Overview of the Carbonic Anhydrases from Two Pathogens of the Oral Cavity: Streptococcus mutans and Porphyromonas gingivalis. Curr. Top. Med. Chem. 2016, 16, 2359-2368. [CrossRef]

13. Supuran, C.T.; Capasso, C. An Overview of the Bacterial Carbonic Anhydrases. Metabolites 2017, 7, 56. [CrossRef]

14. Capasso, C.; Supuran, C.T. An overview of the alpha-, beta- and gamma-carbonic anhydrases from Bacteria: Can bacterial carbonic anhydrases shed new light on evolution of bacteria? J. Enzym. Inhib. Med. Chem. 2015, 30, 325-332. [CrossRef] [PubMed]

15. Del Prete, S.; Nocentini, A.; Supuran, C.T.; Capasso, C. Bacterial iota-carbonic anhydrase: A new active class of carbonic anhydrase identified in the genome of the Gram-negative bacterium Burkholderia territorii. J. Enzyme Inhib. Med. Chem. 2020, 35, 1060-1068. [CrossRef] [PubMed]

16. Supuran, C.T. Advances in structure-based drug discovery of carbonic anhydrase inhibitors. Expert Opin. Drug Discov. 2017, 12, 61-88. [CrossRef]

17. Capasso, C.; Supuran, C.T. Inhibition of Bacterial Carbonic Anhydrases as a Novel Approach to Escape Drug Resistance. Curr. Top. Med. Chem. 2017, 17, 1237-1248. [CrossRef] [PubMed]

18. Supuran, C.T. How many carbonic anhydrase inhibition mechanisms exist? J. Enzym. Inhib. Med. Chem. 2016, 31, 345-360. [CrossRef] [PubMed] 
19. Modak, J.K.; Tikhomirova, A.; Gorrell, R.J.; Rahman, M.M.; Kotsanas, D.; Korman, T.M.; Garcia-Bustos, J.; Kwok, T.; Ferrero, R.L.; Supuran, C.T.; et al. Anti-Helicobacter pylori activity of ethoxzolamide. J. Enzyme Inhib. Med. Chem. 2019, 34, 1660-1667. [CrossRef]

20. Ronci, M.; Del Prete, S.; Puca, V.; Carradori, S.; Carginale, V.; Muraro, R.; Mincione, G.; Aceto, A.; Sisto, F.; Supuran, C.T.; et al. Identification and characterization of the alpha-CA in the outer membrane vesicles produced by Helicobacter pylori. J. Enzyme Inhib. Med. Chem. 2019, 34, 189-195. [CrossRef]

21. Buzas, G.M. Helicobacter pylori-2010. Orv. Hetil. 2010, 151, 2003-2010. [CrossRef] [PubMed]

22. Abuaita, B.H.; Withey, J.H. Bicarbonate Induces Vibrio cholerae virulence gene expression by enhancing ToxT activity. Infect. Immun. 2009, 77, 4111-4120. [CrossRef] [PubMed]

23. Kohler, S.; Ouahrani-Bettache, S.; Winum, J.Y. Brucella suis carbonic anhydrases and their inhibitors: Towards alternative antibiotics? J. Enzyme Inhib. Med. Chem. 2017, 32, 683-687. [CrossRef] [PubMed]

24. Singh, S.; Supuran, C.T. 3D-QSAR CoMFA studies on sulfonamide inhibitors of the Rv3588c beta-carbonic anhydrase from Mycobacterium tuberculosis and design of not yet synthesized new molecules. J. Enzym. Inhib. Med. Chem. 2014, 29, 449-455. [CrossRef]

25. Ceruso, M.; Vullo, D.; Scozzafava, A.; Supuran, C.T. Sulfonamides incorporating fluorine and 1,3,5-triazine moieties are effective inhibitors of three beta-class carbonic anhydrases from Mycobacterium tuberculosis. J. Enzym. Inhib. Med. Chem. 2014, 29, 686-689. [CrossRef] [PubMed]

26. Carta, F.; Maresca, A.; Covarrubias, A.S.; Mowbray, S.L.; Jones, T.A.; Supuran, C.T. Carbonic anhydrase inhibitors. Characterization and inhibition studies of the most active beta-carbonic anhydrase from Mycobacterium tuberculosis, Rv3588c. Bioorg. Med. Chem. Lett. 2009, 19, 6649-6654. [CrossRef]

27. Rollenhagen, C.; Bumann, D. Salmonella enterica highly expressed genes are disease specific. Infect. Immun. 2006, 74, 1649-1660. [CrossRef] [PubMed]

28. Lotlikar, S.R.; Kayastha, B.B.; Vullo, D.; Khanam, S.S.; Braga Reygan, E.; Murray, A.B.; McKenna, R.; Supuran, C.T.; Patrauchan, M.A. Pseudomonas aeruginosa $\beta$-carbonic anhydrase, psCA1, is required for calcium deposition and contributes to virulence. Cell Calcium 2019, 84, 102080. [CrossRef]

29. Capasso, C.; Supuran, C.T. Sulfa and trimethoprim-like drugs-Antimetabolites acting as carbonic anhydrase, dihydropteroate synthase and dihydrofolate reductase inhibitors. J. Enzym. Inhib. Med. Chem. 2014, 29, 379-387. [CrossRef]

30. Jensen, E.L.; Clement, R.; Kosta, A.; Maberly, S.C.; Gontero, B. A new widespread subclass of carbonic anhydrase in marine phytoplankton. ISME J. 2019, 13, 2094-2106. [CrossRef]

31. Kikutani, S.; Nakajima, K.; Nagasato, C.; Tsuji, Y.; Miyatake, A.; Matsuda, Y. Thylakoid luminal theta-carbonic anhydrase critical for growth and photosynthesis in the marine diatom Phaeodactylum tricornutum. Proc. Natl. Acad. Sci. USA 2016, 113, 9828-9833. [CrossRef] [PubMed]

32. Supuran, C.T. Carbonic anhydrases: Novel therapeutic applications for inhibitors and activators. Nat. Rev. Drug Discov. 2008, 7, 168-181. [CrossRef] [PubMed]

33. Alterio, V.; Di Fiore, A.; D’Ambrosio, K.; Supuran, C.T.; De Simone, G. Multiple binding modes of inhibitors to carbonic anhydrases: How to design specific drugs targeting 15 different isoforms? Chem. Rev. 2012, 112, 4421-4468. [CrossRef] [PubMed]

34. Supuran, C.T.; Capasso, C. Biomedical applications of prokaryotic carbonic anhydrases. Expert Opin. Pat. 2018, 28, 745-754. [CrossRef]

35. Supuran, C.T.; Capasso, C. Carbonic Anhydrase from Porphyromonas Gingivalis as a Drug Target. Pathogens 2017, 6, 30. [CrossRef]

36. Ozensoy Guler, O.; Supuran, C.T.; Capasso, C. Carbonic anhydrase IX as a novel candidate in liquid biopsy. J. Enzym. Inhib. Med. Chem. 2020, 35, 255-260. [CrossRef]

37. Neri, D.; Supuran, C.T. Interfering with $\mathrm{pH}$ regulation in tumours as a therapeutic strategy. Nat. Rev. Drug Discov. 2011, 10, 767-777. [CrossRef]

38. Capasso, C.; Supuran, C.T. An Overview of the Selectivity and Efficiency of the Bacterial Carbonic Anhydrase Inhibitors. Curr. Med. Chem. 2015, 22, 2130-2139. [CrossRef]

39. Supuran, C.T.; Capasso, C. New light on bacterial carbonic anhydrases phylogeny based on the analysis of signal peptide sequences. J. Enzyme Inhib. Med. Chem. 2016, 31, 1254-1260. [CrossRef] 
40. De Simone, G.; Monti, S.M.; Alterio, V.; Buonanno, M.; De Luca, V.; Rossi, M.; Carginale, V.; Supuran, C.T.; Capasso, C.; Di Fiore, A. Crystal structure of the most catalytically effective carbonic anhydrase enzyme known, SazCA from the thermophilic bacterium Sulfurihydrogenibium azorense. Bioorg. Med. Chem. Lett. 2015, 25, 2002-2006. [CrossRef]

41. Alafeefy, A.M.; Abdel-Aziz, H.A.; Vullo, D.; Al-Tamimi, A.M.; Al-Jaber, N.A.; Capasso, C.; Supuran, C.T. Inhibition of carbonic anhydrases from the extremophilic bacteria Sulfurihydrogenibium yellostonense (SspCA) and S. azorense (SazCA) with a new series of sulfonamides incorporating aroylhydrazone-, $[1,2,4]$ triazolo[3,4-b][1,3,4]thiadiazinyl- or 2-(cyanophenylmethylene)-1,3,4-thiadiazol-3(2H)-yl moieties. Bioorg. Med. Chem. 2014, 22, 141-147.

42. Vullo, D.; De Luca, V.; Scozzafava, A.; Carginale, V.; Rossi, M.; Supuran, C.T.; Capasso, C. The extremo-alpha-carbonic anhydrase from the thermophilic bacterium Sulfurihydrogenibium azorense is highly inhibited by sulfonamides. Bioorg. Med. Chem. 2013, 21, 4521-4525. [CrossRef]

43. Cronk, J.D.; Endrizzi, J.A.; Cronk, M.R.; O’Neill, J.W.; Zhang, K.Y. Crystal structure of E. coli beta-carbonic anhydrase, an enzyme with an unusual pH-dependent activity. Protein Sci. 2001, 10, 911-922. [CrossRef]

44. Merlin, C.; Masters, M.; McAteer, S.; Coulson, A. Why is carbonic anhydrase essential to Escherichia coli? J. Bacteriol. 2003, 185, 6415-6424. [CrossRef]

45. Clermont, O.; Olier, M.; Hoede, C.; Diancourt, L.; Brisse, S.; Keroudean, M.; Glodt, J.; Picard, B.; Oswald, E.; Denamur, E. Animal and human pathogenic Escherichia coli strains share common genetic backgrounds. Infect. Genet. Evol. 2011, 11, 654-662. [CrossRef] [PubMed]

46. Reid, S.D.; Herbelin, C.J.; Bumbaugh, A.C.; Selander, R.K.; Whittam, T.S. Parallel evolution of virulence in pathogenic Escherichia coli. Nature 2000, 406, 64-67. [CrossRef] [PubMed]

47. Szych, J.; Wolkowicz, T.; La Ragione, R.; Madajczak, G. Impact of antibiotics on the intestinal microbiota and on the treatment of Shiga-toxin-producing Escherichia coli and Salmonella infections. Curr. Pharm. Des. 2014, 20, 4535-4548. [CrossRef] [PubMed]

48. Pitout, J.D. Extraintestinal Pathogenic Escherichia coli: A Combination of Virulence with Antibiotic Resistance. Front. Microbiol. 2012, 3, 9. [CrossRef]

49. Nataro, J.P.; Kaper, J.B. Diarrheagenic Escherichia coli. Clin. Microbiol. Rev. 1998, 11, 142-201. [CrossRef]

50. Moriel, D.G.; Bertoldi, I.; Spagnuolo, A.; Marchi, S.; Rosini, R.; Nesta, B.; Pastorello, I.; Corea, V.A.; Torricelli, G.; Cartocci, E.; et al. Identification of protective and broadly conserved vaccine antigens from the genome of extraintestinal pathogenic Escherichia coli. Proc. Natl. Acad. Sci. USA 2010, 107, 9072-9077. [CrossRef]

51. Agus, A.; Massier, S.; Darfeuille-Michaud, A.; Billard, E.; Barnich, N. Understanding host-adherent-invasive Escherichia coli interaction in Crohn's disease: Opening up new therapeutic strategies. Biomed. Res. Int. 2014, 2014, 567929. [CrossRef]

52. Supuran, C.T. Structure-based drug discovery of carbonic anhydrase inhibitors. J. Enzym. Inhib. Med. Chem. 2012, 27, 759-772. [CrossRef] [PubMed]

53. Supuran, C.T. Structure and function of carbonic anhydrases. Biochem. J. 2016, 473, 2023-2032. [CrossRef] [PubMed]

54. Kozliak, E.I.; Guilloton, M.B.; Gerami-Nejad, M.; Fuchs, J.A.; Anderson, P.M. Expression of proteins encoded by the Escherichia coli cyn operon: Carbon dioxide-enhanced degradation of carbonic anhydrase. J. Bacteriol. 1994, 176, 5711-5717. [CrossRef] [PubMed]

55. De Luca, V.; Del Prete, S.; Supuran, C.T.; Capasso, C. Protonography, a new technique for the analysis of carbonic anhydrase activity. J. Enzyme Inhib. Med. Chem. 2015, 30, 277-282. [CrossRef] [PubMed]

56. Del Prete, S.; Vullo, D.; De Luca, V.; Carginale, V.; di Fonzo, P.; Osman, S.M.; AlOthman, Z.; Supuran, C.T.; Capasso, C. Anion inhibition profiles of alpha-, beta- and gamma-carbonic anhydrases from the pathogenic bacterium Vibrio cholerae. Bioorg. Med. Chem. 2016, 24, 3413-3417. [CrossRef] [PubMed]

57. Nguyen, K.; Ahlawat, R. Famotidine. In StatPearls; StatPearls Publishing: Treasure Island, FL, USA, 2020. Available online: https://www.ncbi.nlm.nih.gov/books/NBK534778/ (accessed on 10 June 2020).

58. Komiya, T.; Huang, C.H. Updates in the Clinical Development of Epacadostat and Other Indoleamine 2,3-Dioxygenase 1 Inhibitors (IDO1) for Human Cancers. Front. Oncol. 2018, 8, 423. [CrossRef]

59. Del Prete, S.; Vullo, D.; De Luca, V.; Carginale, V.; Osman, S.M.; AlOthman, Z.; Supuran, C.T.; Capasso, C. Comparison of the sulfonamide inhibition profiles of the alpha-, beta- and gamma-carbonic anhydrases from the pathogenic bacterium Vibrio cholerae. Bioorg. Med. Chem. Lett. 2016, 26, 1941-1946. [CrossRef] 
60. Angeli, A.; Ferraroni, M.; Supuran, C.T. Famotidine, an Antiulcer Agent, Strongly Inhibits Helicobacter pylori and Human Carbonic Anhydrases. ACS Med. Chem. Lett. 2018, 9, 1035-1038. [CrossRef]

61. Del Prete, S.; Vullo, D.; Ghobril, C.; Hitce, J.; Clavaud, C.; Marat, X.; Capasso, C.; Supuran, C.T. Cloning, Purification, and Characterization of a beta-Carbonic Anhydrase from Malassezia restricta, an Opportunistic Pathogen Involved in Dandruff and Seborrheic Dermatitis. Int. J. Mol. Sci. 2019, 20, 2447. [CrossRef]

62. Bradford, M.M. A rapid and sensitive method for the quantitation of microgram quantities of protein utilizing the principle of protein-dye binding. Anal. Biochem. 1976, 72, 248-254. [CrossRef]

63. Capasso, C.; De Luca, V.; Carginale, V.; Cannio, R.; Rossi, M. Biochemical properties of a novel and highly thermostable bacterial alpha-carbonic anhydrase from Sulfurihydrogenibium yellowstonense YO3AOP1. J. Enzym. Inhib. Med. Chem. 2012, 27, 892-897. [CrossRef] [PubMed]

64. Laemmli, U.K. Cleavage of structural proteins during the assembly of the head of bacteriophage T4. Nature 1970, 227, 680-685. [CrossRef] [PubMed]

65. Del Prete, S.; De Luca, V.; Iandolo, E.; Supuran, C.T.; Capasso, C. Protonography, a powerful tool for analyzing the activity and the oligomeric state of the gamma-carbonic anhydrase identified in the genome of Porphyromonas gingivalis. Bioorg. Med. Chem. 2015, 23, 3747-3750. [CrossRef] [PubMed]

66. Del Prete, S.; De Luca, V.; Supuran, C.T.; Capasso, C. Protonography, a technique applicable for the analysis of eta-carbonic anhydrase activity. J. Enzym. Inhib. Med. Chem. 2015, 30, 920-924. [CrossRef]

67. Del Prete, S.; Vullo, D.; Caminiti-Segonds, N.; Zoccola, D.; Tambutte, S.; Supuran, C.T.; Capasso, C. Protonography and anion inhibition profile of the alpha-carbonic anhydrase (CruCA4) identified in the Mediterranean red coral Corallium rubrum. Bioorg. Chem. 2018, 76, 281-287. [CrossRef]

68. Khalifah, R.G. The carbon dioxide hydration activity of carbonic anhydrase. I. Stop-flow kinetic studies on the native human isoenzymes B and C. J. Biol. Chem. 1971, 246, 2561-2573.

69. Del Prete, S.; Vullo, D.; De Luca, V.; Carginale, V.; di Fonzo, P.; Osman, S.M.; AlOthman, Z.; Supuran, C.T.; Capasso, C. Anion inhibition profiles of the complete domain of the eta-carbonic anhydrase from Plasmodium falciparum. Bioorg. Med. Chem. 2016, 24, 4410-4414. [CrossRef]

70. De Luca, V.; Vullo, D.; Del Prete, S.; Carginale, V.; Osman, S.M.; AlOthman, Z.; Supuran, C.T.; Capasso, C. Cloning, characterization and anion inhibition studies of a gamma-carbonic anhydrase from the Antarctic bacterium Colwellia psychrerythraea. Bioorg. Med. Chem. 2016, 24, 835-840. [CrossRef] 